\title{
Estimating sedimentary thickness of Lanka Basin using digitised scanned seismic sections
}

\author{
K.C.C. Silva ${ }^{1}$, N.G.S. Shantha Gamage ${ }^{1^{*}}$ and D.A. Weerasinghe ${ }^{2}$ \\ ${ }^{1}$ Department of Physics, Faculty of Applied Sciences, University of Sri Jayewardenepura, Gangodawila, Nugegoda. \\ 2 Petroleum Resources Development Secretariat, Ceylinco House, Colombo.
}

Submitted: 09 May 2018; Revised: 16 May 2019; Accepted: 24 May 2019

\begin{abstract}
In exploration geophysics, seismic surveys and their interpretations provide the most reliable information of the subsurface structures. Extensive work on the determination of the subsurface structure has been carried out in both Cauvery and Mannar basins of offshore Sri Lanka. Freely available satellite- gravity and magnetic data suggest that the Lanka Basin may have the necessary sediment volume for the occurrence of hydrocarbons. However, without seismic data, this suggestion cannot be tested further. As an alternative to acquiring additional seismic data in the region, this research focused on digitising $50,000 \mathrm{~km}$ of vintage seismic lines from the National Geophysical Data Centre (NGDC) data repository and converting them into Seg-Y format. Key seismic horizons on the digitised sections were interpreted to provide details of the seabed and acoustic basement in the time domain. Regional sedimentary thickness maps were compiled in the time domain interpolating the interpreted horizons using 'kriging' method. The velocity data acquired in the region were used to convert the maps from time to depth domain. The results indicate that average thickness of sediments in the region varies around $5000 \mathrm{~m}$ to $6000 \mathrm{~m}$, where the maximum thickness is around $8000 \mathrm{~m}$ in the North Eastern part of the Lanka basin. The thickness maps can be used as a reference dataset to plan commercial seismic surveys in the future for hydrocarbon exploration in the Lanka Basin.
\end{abstract}

Keywords: Lanka basin, NGDC, passive margins, seismic surveys, thickness model.

\section{INTRODUCTION}

Geophysical techniques such as seismic, gravity, magnetic and electrical surveys are employed in the present scenario mainly in prospecting for natural resources buried underneath. They also provide information on the existence of structural and lithological variations in the subsurface. Exploring for these resources could be a great financial burden, especially for developing countries. Petroleum exploration in Sri Lanka began approximately 50 years ago and currently the Petroleum Resources Development Secretariat (PRDS) manages all the data belonging to the upstream industry of the country (Tantrigoda, 2010). Extensive exploration work has been carried out in both Cauvery (Chandra et al., 1991; Baillie et al., 2002) and Mannar (Premarathne et al., 2013; Kularathna et al., 2015a; Ratnayake et al., 2014) basins. Although the interest in exploration for hydrocarbon in the ultra-deep Lanka Basin has been recently established, it has been hindered by the lack of data in the region (Rathnayaka et al., 2017; Gamage et al., 2018; 2019). The Lanka Basin is thought to have opened up when Antarctica separated from the eastern India and Sri Lanka 142 Ma ago (Kularathna et al., 2015b). During the rifting phase, Cretaceous sediments may have been deposited in the basin. Thereafter, the sediment supply to the passive margin might have significantly increased during the Late Oligocene age when the Indian and the Eurasian plates collided to form the Himalayan mountain range and started to form major rivers like the Ganges and Brahmaputra (Nairn \& Stehli, 1982; Curray, 1994). Furthermore, the freely available satellite gravity and magnetic data suggest that the Lanka Basin could have possessed the necessary sedimentary thickness and structures required

*Corresponding author (shanthagamage@sci.sjp.ac.lk; (iD http://orcid.org/0000-0003-1639-4836)

This article is published under the Creative Commons CC-BY-ND License (http://creativecommons.org/licenses/by-nd/4.0/). This license permits use, distribution and reproduction, commercial and non-commercial, provided that the original work is properly cited and is not changed in anyway. 
for hydrocarbon occurrences. However, without seismic data, the above claim and the existence of other major elements to have a working petroleum system cannot be proven. As an alternative to acquiring more seismic data, which involves a large cost and extensive national planning, a study using vintage seismic data acquired in the past may provide useful information about the region as well. The preliminary data for the interested region was obtained from the National Geophysical Data Centre (NGDC) of the USA. If a sedimentary thickness model can be created for the Lanka basin using existing seismic data available in the NGDC website, we can get some basic idea about sedimentary distribution in the Lanka basin. Thereafter, based on those details we can plan the next commercial seismic survey to find oil/gas reservoirs buried in the Lanka Basin.

\section{METHODOLOGY}

The data for the interested region (Figure 1) was obtained from the NGDC, USA. The data files contained two parts; the first section contained survey details in ASCII format and the second section contained time-migrated seismic section in a JPEG/TIFF format. A customised process (Figure 2) was developed to carry out the digitisation of 50,000 km of scanned seismic images (Silva et al., 2018).

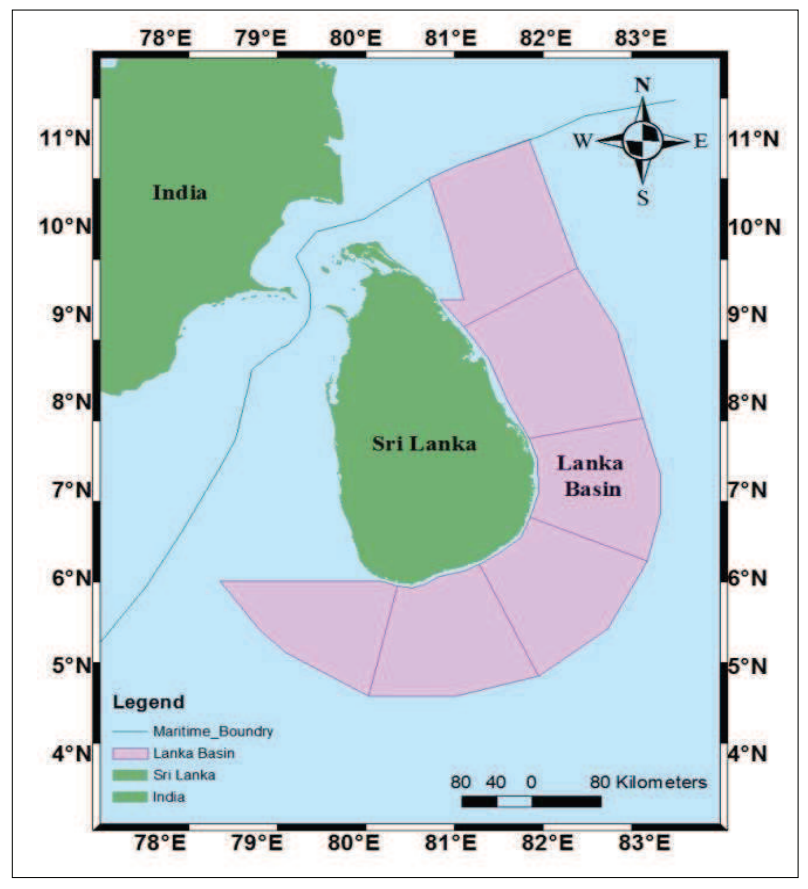

Figure 1: Study area for sedimentary thickness model
After creating this comprehensive database of the seismic sections, the data was interpreted to generate a sedimentary thickness map in the passive margin area of the Lanka basin. The sea bed and the reflector, assumed to be the basement (acoustic basement) were interpreted using the IHS Kingdom suit software and a sedimentary thickness grid in Two Way Time (TWT) was generated. The velocity details to convert the TWT into depth domain were obtained from previous seismic studies conducted in the Eastern side of the Bay of Bengal (Hamilton et al., 1974; Rao et al., 1997). Therefore, the average velocity $\left(\mathrm{V}_{\mathrm{A}}\right)$ of the sedimentary section was obtained by converting the interval velocities using the following equation.

$V_{A}=\frac{\sum_{i=1}^{n} \mathrm{v}_{\mathrm{i}} \tau_{i}}{\sum_{i=1}^{n} \tau_{i}}$

$\tau_{\mathrm{i}}=$ one way travel time, $v_{\mathrm{i}}=$ velocity in the $\mathrm{i}^{\text {th }}$ layer

Then, the thickness of the $i^{\text {th }}$ layer is given by,

$D=V_{A} \times \tau_{i}$

For the purpose of enhancing the details of the digitised seismic database, topography and gravity data were

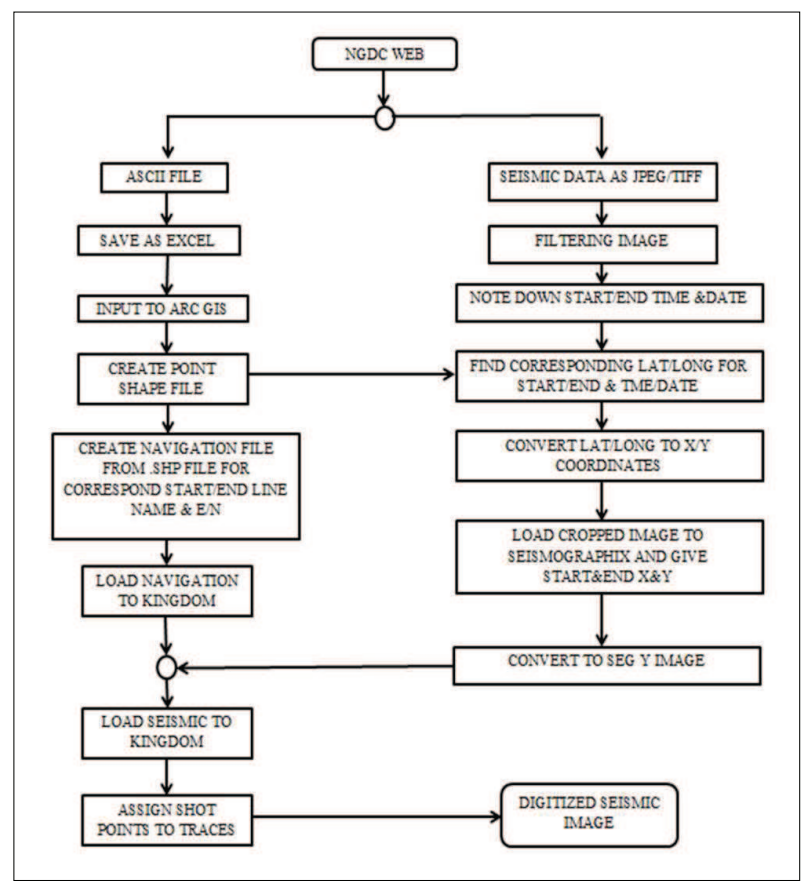

Figure 2: Process of digitising scanned seismic images 
accessed from http://topex.ucsd.edu and used to create time and depth domain grids. To create these grids, kriging algorithm was applied and the grid cell size of $1000 \mathrm{~m}$ by $1000 \mathrm{~m}$ was selected. Topography and gravity data were used to get a better understanding of the sea floor change and to predict the variations of acoustic basement.

\section{RESULTS AND DISCUSSION}

Using the defined methodology (Figure 2), 13 seismic surveys and about 400 scanned paper copies were digitised and converted to SEG-Y format. Two examples of seismic sections including the interpreted seabed and basement horizons are given in Figures 3(a) and 3(b).

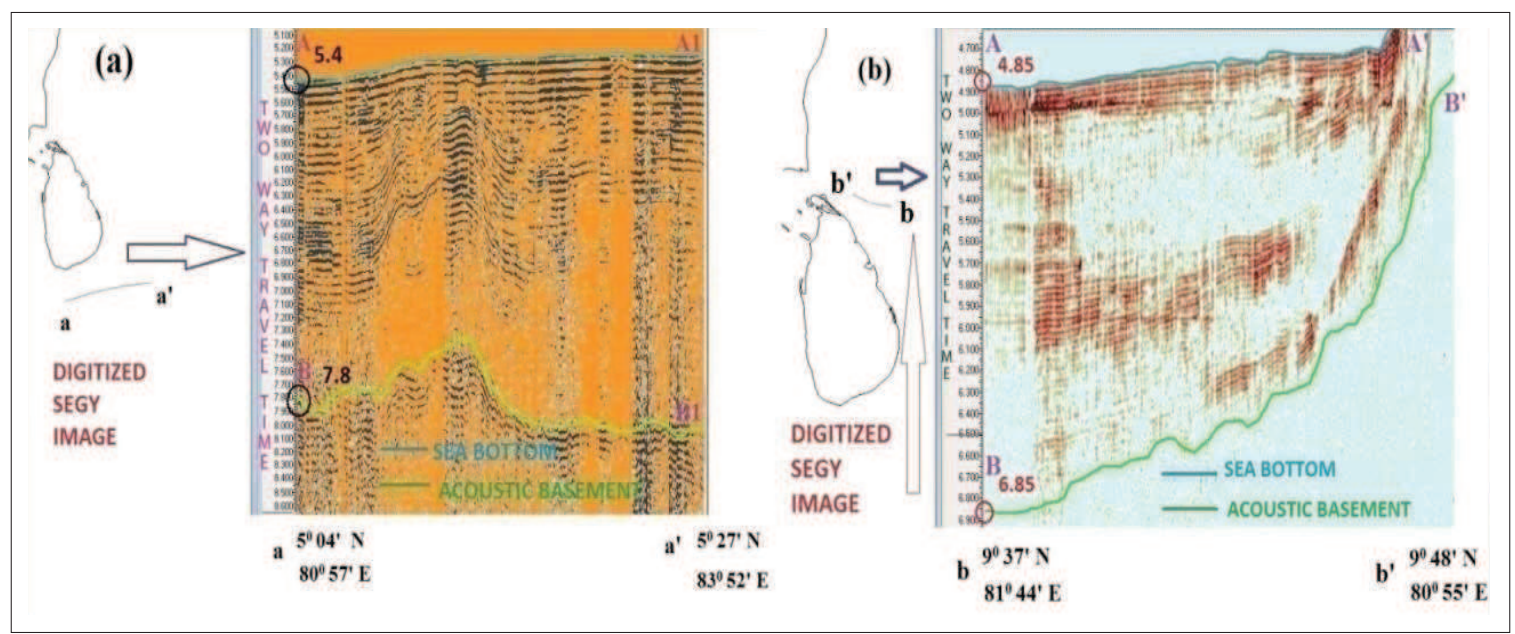

Figure 3: Images (a) and (b) show seismic charts for two different locations. Sea bottom (upper interpreted line) and acoustic basement (bottom interpreted line) are indicated in the images

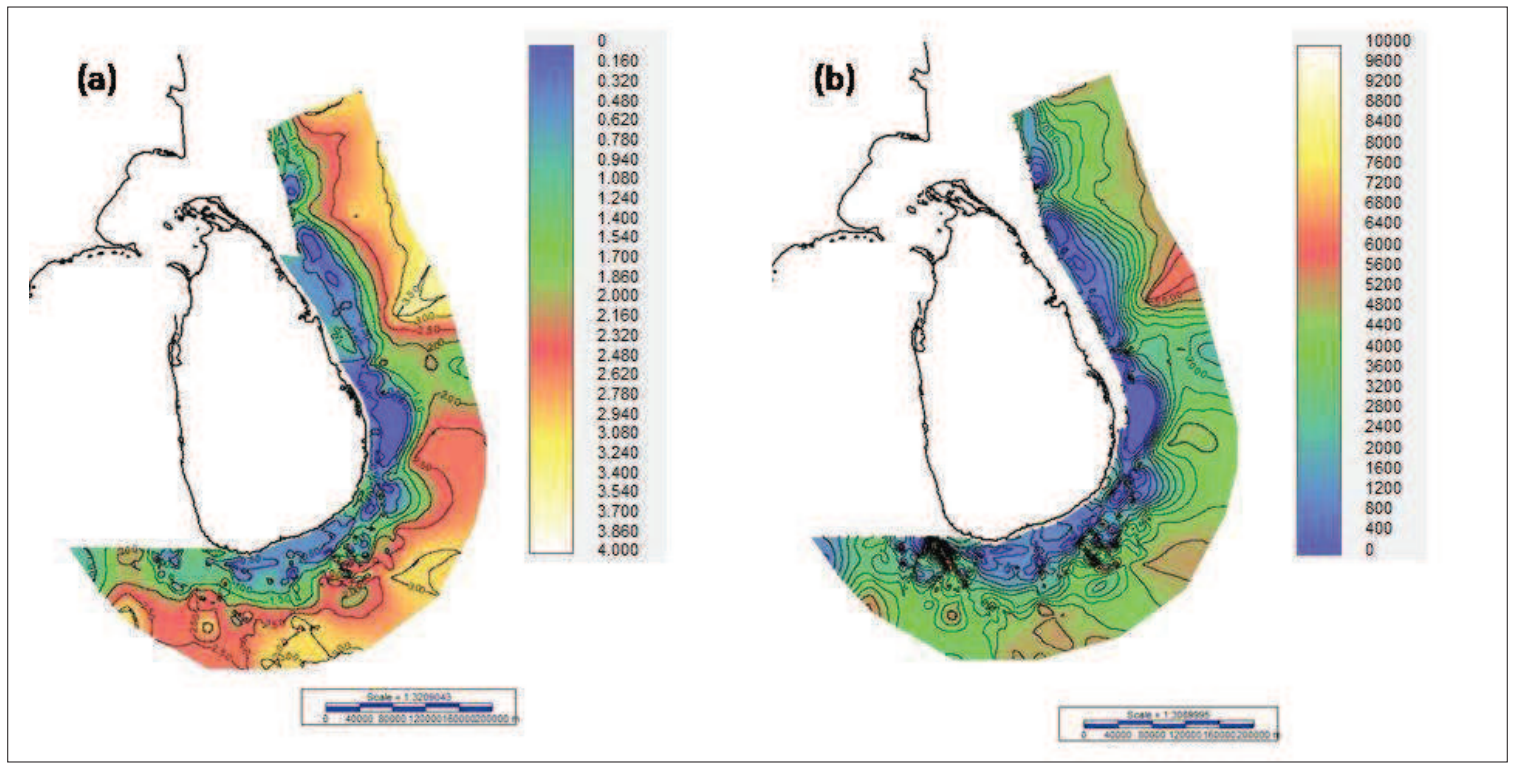

Figure 4: Images (a) and (b) show the sediment thickness in time and depth domain, respectively 
The sedimentary thickness maps generated in both time and depth domain for the Lanka Basin area are given in Figures 4(a) and 4(b). The acoustic velocity in the water column was taken as $1500 \mathrm{~ms}^{-1}$ and the calculated average velocity in the sedimentary section was around $3300 \mathrm{~ms}^{-1}$. The average sediment thickness in the region varies from $5000 \mathrm{~m}$ to $6000 \mathrm{~m}$ whereas the maximum sediment thickness was around $8000 \mathrm{~m}$ in the North Eastern part of the Lanka basin.

The main difficulty faced in the study was the fact that the seismic data have non-unique standards and the presence of considerable amount of noise, since they were collected in different time periods (Blake \& Hewlett, 1993), which had to be solved using various image processing methods. Furthermore, it was difficult to interpret the basement horizon because of the extensive noise that had occurred due to poor quality of the images and the fact that the older equipment failing to generate and record lower frequency data, which provide information on the deeper targets. The depth conversion would have been more accurate if a velocity model was built using more points and by considering the increment of velocity with depth.

Along the sedimentary thickness grid in the depth domain, crosslines were drawn to view the sediment thickness variation in the Lanka Basin. Using the bathymetry grid, sea floor change can also be checked.

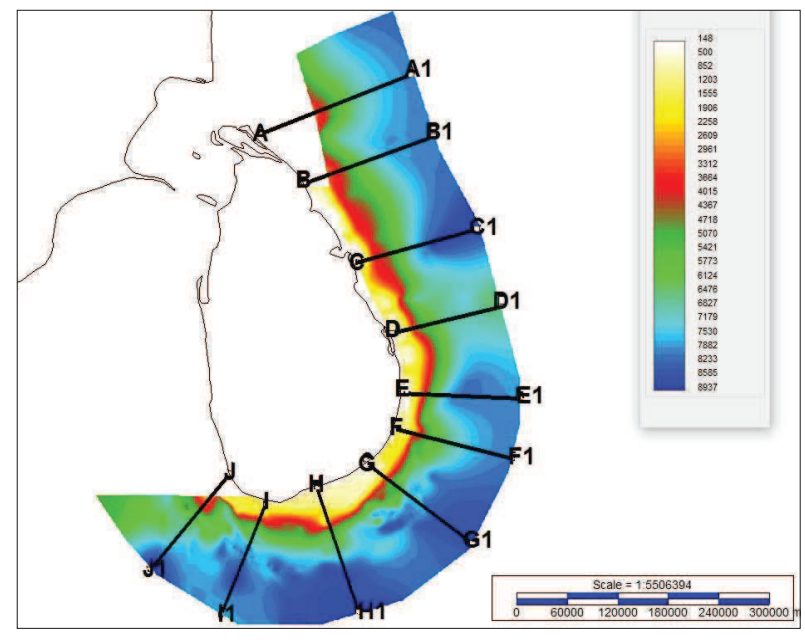

Figure 5: Image showing cross sections in Lanka Basin

Figure 7 shows the details of sedimentary thickness, seafloor change and the gravity anomaly along the crossline G-G1. The gravity and seafloor (bathymetry) values were direct observations and they have higher accuracy compared to the sedimentary thickness values, which were calculated using digitised seismic images. Gravity values have been scaled $(* 100)$ to correlate with thickness and bathymetry values. Here, the attempt was to increase the validity of sedimentary thickness values using gravity and bathymetry values in the region.
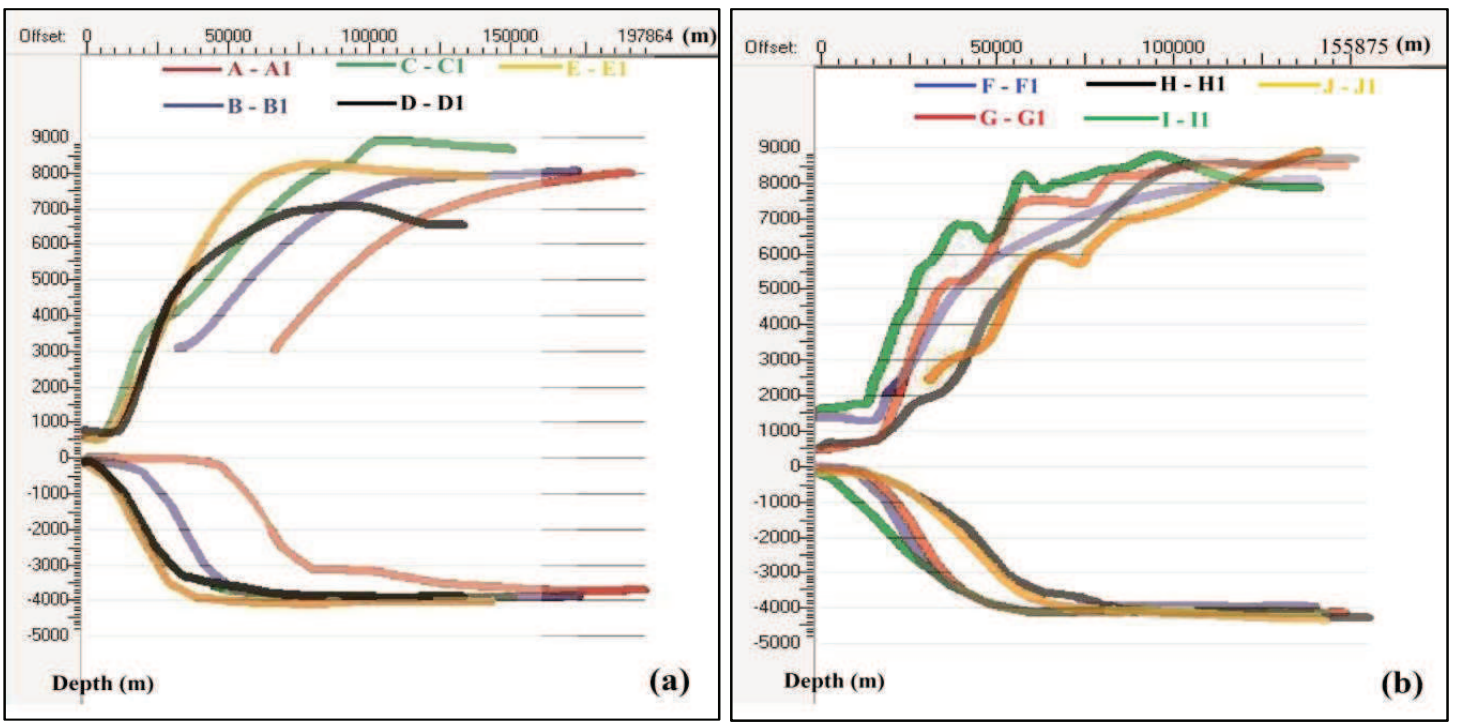

Figure 6: Variation of sedimentary thickness and sea floor change along the crosslines drawn in Figure 5 


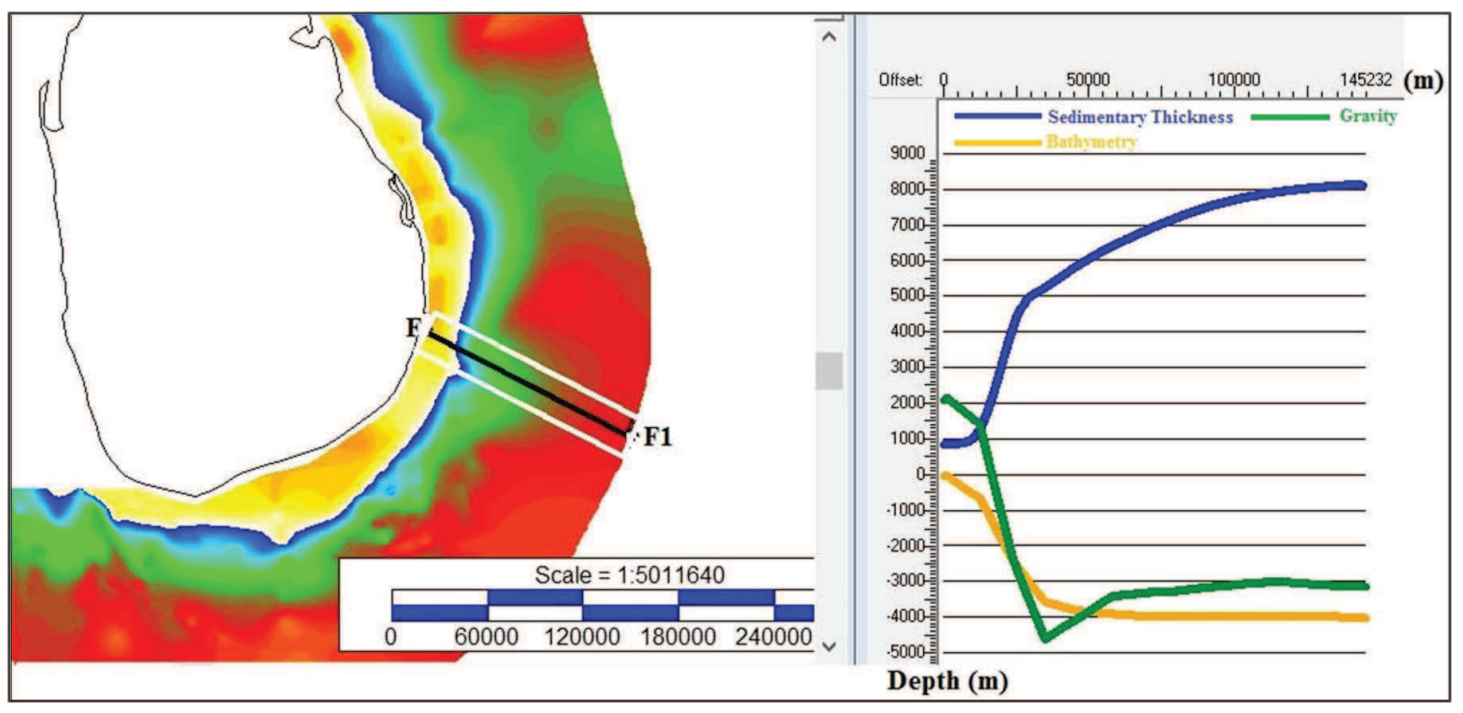

Figure 7: Sedimentary thickness, bathymetry and gravity values along the FF1 crossline

In Figure 7, the sedimentary thickness value increased along the F-F1 line, from the coastal margin to the outer edge of the thickness grid. Bathymetry values started from 0 and decreased (depth increasing) up to $4000 \mathrm{~m}$ and remained constant along the line. Gravity values showed the negative gravity anomaly until seafloor decrease. Explanation for this scenario was that the higher dense land masses were replaced by the lesser dense water column causing the negative gravity anomaly shown. The focus here was that after the sea floor values became constant, there was an increment of gravity values (decrease negatively) in the relevant section. As discussed before, when the seafloor decrement (increment of water column) affects the negative gravity anomaly and after the seafloor takes a constant value, another parameter should have caused that sudden increment in gravity values. In Figure 7, there was an increment in the sedimentary thickness in the region where the sea floor takes a constant value and also shows a gravity increment. After considering these facts, a conclusion can be made to depict the increment of sedimentary thickness affecting the sudden increment of gravity values where the sea floor takes a constant value. Using these directly observed gravity and bathymetry values, the accuracy of the sedimentary thickness model created can be increased and could be used to create more accurate hypotheses.

\section{CONCLUSION}

The interpretation of the digitised seismic data suggests that an average sedimentary thickness of $5000 \mathrm{~m}$ to $6000 \mathrm{~m}$ is present in the Lanka Basin and the maximum sedimentary thickness is around $8000 \mathrm{~m}$ in the North Eastern part of the Lanka Basin. A sudden decrement of the sedimentary thickness off the coast of Batticaloa was observed and it may be due to a shallow compressional feature or an underlying ridge in the region. The thickness model can be used to determine the hydrocarbon prospectivity of the region, and as a reference dataset to plan commercial seismic surveys in future for hydrocarbon exploration in the Lanka Basin.

\section{Acknowledgement}

Authors wish to acknowledge the University of Sri Jayewardenepura for providing financial support under the research grant No. ASP/01/RE/SCI/2018/16, and the Petroleum Resources Development Secretariat for providing required data and facilities to conduct the research.

\section{REFERENCES}

Baillie P.W., Liyanaarachchi D.T.P. \& Jayaratne M.G. (2002). A new Mesozoic sedimentary basin, offshore Sri Lanka. Petromin 28(4): 53-57.

Blake N. \& Hewlett C. (1993). Digital information recovery from paper seismic sections for work station loading. Jeofizik 7(1): 3-14.

Chandra K., Philip P.C., Sridharan P., Chopra V.S., Rao B. \& Saha P.K. (1991). Petroleum source-rock potentials of the Cretaceous transgressive-regressive sedimentary sequences of the Cauvery Basin. Journal of Southeast Asian Earth 
Sciences 5(1-4): 367-371.

Curray J.R. (1994). Sediment volume and mass beneath the Bay of Bengal. Earth and Planetary Science Letters 125 (1-4): 371-383.

Gamage S.S.N., Ratnayake R.M.T.S., Senadhira A., Weerasinghe D.A. \& Waduge V.A. (2018). Radioactive and non-radioactive element analysis of Dorado gas discovery of Sri Lanka and their influence on natural environment. Journal of Tropical Forestry and Environment 8(1): 55-63. DOI: https://doi.org/10.31357/jtfe.v8i1.3483

Gamage S.S.N., Silva K.C.C. \& Weerasinghe D.A. (2019). Subsurface structure of the offshore Trincomalee, NE of Sri Lanka. The Journal of Indian Geophysical Union 23(3): 214-222.

Hamilton E.L., Moore D.G., Buffington E.C., Sherrer P.L. \& Curray J.R. (1974). Sediment velocities from sonobuoys: Bay of Bengal, Bering Sea, Japan Sea, and North Pacific. Journal of Geophysical Research 79(17): 26532668.

DOI: https://doi.org/10.1029/JB079i017p02653

Kularathna E.K.C.W., Pitawala H.M.T.G.A., Senarathne A., Senevirathne B.S.M.C.K. \& Weerasinghe D.A. (2015a). Forced-fold structures in the Mannar Basin, Sri Lanka: modes of occurrence, development mechanism and contribution for the petroleum system. Journal of Geological Society of Sri Lanka 17(1): 53-63.

Kularathna E.K.C.W., Pitawala H.M.T.G.A. \& Senarathne A. (2015b). Gondwana breakup and development of sedimentary basins in Sri Lanka. Proceedings of the $31^{\text {st }}$ Technical Session of the Geological Society of Sri Lanka, p. 6 .

Nairn A.E.M. \& Stehli F.G. (1982). The Ocean Basins and Margins: The Indian Ocean, volume 6, p. 3. Plenum Press,
New York and London.

DOI: https://doi.org/10.1007/978-1-4615-8038-6

Premarathne D.M.U.A.K., Suzuki N., Ratnayake N.P. \& Kularathne E.K.C.W. (2013). A petroleum system in the Gulf of Mannar Basin, offshore Sri Lanka. Proceedings of the $29^{\text {th }}$ Technical Sessions of the Geological Society of Sri Lanka, p. 12.

Rao D.G., Krishna K.S. \& Sar D. (1997). Crustal evolution and sedimentation history of the Bay of Bengal since the Cretaceous. Journal of Geophysical Research: Solid Earth 102(B8): 17747-17768.

DOI: https://doi.org/10.1029/96JB01339

Ratnayake A.S., Sampei Y. \& Kularathne C.W. (2014). Stratigraphic responses to major depositional events from the Late Cretaceous to Miocene in the Mannar Basin, Sri Lanka. Journal of the Geological Society of Sri Lanka 16(1): 5-18.

Ratnayake R.M.T.S., Gamage S.S.N., Senadhira A., Weerasinghe D.A. \& Waduge V.A. (2017). NORM analysis of the reservoir sand section in the Dorado natural gas discovery, Mannar Basin offshore Sri Lanka. Journal of Geological Society of India 89(6): 683-688.

DOI: https://doi.org/10.1007/s12594-017-0679-7

Silva K.C.C., Gamage S.S.N. \& Weerasinghe D.A. (2018). Digitising scanned seismic sections of the Southern and North Eastern Indian Ocean regions adjoining Sri Lanka. Proceedings of the $34^{\text {th }}$ Technical Sessions of the Institute of Physics Sri Lanka, pp. 51-57.

Tantrigoda D.A. (2010). Claiming the sea area belonging to Sri Lanka according to the United Nations Convention on the Law of the Sea (UNCLOS). Journal of the National Science Foundation of Sri Lanka 38(1): 1-2. DOI: https://doi.org/10.4038/jnsfsr.v38i1.1720 